\title{
English Popular Preaching in the Fourteenth Century
}

THE Friars Minor, or, as men called them, the Grey Friars, came to England in 1224, missionaries to the poor of the town populations; they came among them as the poor to the poor, rich only in eympathy and in the Word of God; barefoot, and begging their daily bread, they did no more than build mud or wooden huts to shelter their amall compenies in the midst of the poor and squalid surroundings among which lay their work. If a piece of ground was given to them, they dag a ditch round it, with a wooden fence instead of a wall, built their cottages and cells in which to labour and to pray, and a small poor church, without painting or ornament, in which to preach. Penurions in their cheerful self-renunciation, they devoted themselves to the ignorant and needy, labouring also among the outcast lepers. But they were not allowed to acquire or retain books and learning. St. Francis feared that the scholastic learning and legal theological subtleties of his day might draw his followers from their path. He shunned it all. It was not mental discipline that he cared for, but discipline of the heart and character. And the English Minorites, we are told, were the strictest adherents to his rules.

Yet preaching and teaching, which were a chief part of their duty, and in their hands acquired a distinctive character, must before long have required some relaxation of the prohibition of books.

The necessities of the class for whom they laboured (says Mr. Brewer) brought out in the Franciscan a style of living and preaching suitable to his auditory; he hed to speak to the hearts of men and women who were not learned; he had to stady those hearts and what was in them before he could hope to address them with success. His poverty ensbled him to accomplish the first and most difficult portion of his task by throwing him upon the help and sympathy of those for whom he laboured. The necessity of alms from day to day, the stringent rale imposed by his founder, forced him from a life of mere study or contemplation into a life of activity. . . Preaching must become the great object of his life, quite as much as poverty; bat it was a new stgle of instruction, very different 
from that which had hitherto prevailed . . . suiled to an andience consisting as much of women as of men, sppesling more directly to the feelings, more popular and more dramatio. ${ }^{1}$

Clearly, then, the order, which was joined by men of all ranks and of all degrees of learning, could not afford to neglect stady, and their rank and file must be assisted to procure a good foundation on which the enthusiasm for humanity might work apwards.

Accordingly, before many summers had passed, Brother Agnellus, the first provincial in England (died 1232), had built a school at Oxford, where Bishop Grostête, Adem de Marisco (himself in the order), and others lectured with much success; and within twenty or thirty years there were thirty lecturers established by the Minorites at different places in England. The friars made great progress with their sermons and moralities; they became so famous for their studies that the French sent for two brethren, Philip and Adam, to read lectures at Lyons; and we know that Brothers Bartholomew and Johw, Englishmen, the former of whom also attained fame as a lecturer on the Scriptures in Paris, were sent in 1231 to assist in establishing and teaching holy theology in the new province of the order in Saxony. 'The gift of wisdom,' says the Minorite chronicler, Eccleston, with delight, "so overflowed in Englend.'

Contrary to the practice of St. Francis, Grostete arged the friars to the study of theology, not to 'walk to their shame in. the darkness of ignorance.' The wise and experienced Adam de Marisco interceded that a promising student might have books. And these stadies of the closet were tempered and vivified by their practical labours among the people; 'the early scholars of the order alternated study with preaching.'

The necessities of their daily work thus brought them a liberty of discussion, their training a freedom and vigonr of mind, which gave a new impulse to the mental history of the middle ages. In their search for ideas and images suited to convey the truths of Scripture and to impress the moral dicta home upon their hearere by familiar comparisons, they seized upon the natural facts round about them, ransacked old and foreign writers for the marvels of nature recorded, and applied these to their teaching, in a manner which may now often seem to us fanciful, but which must have greatly spread general knowledge in those days of little reading but much listening.

The first observations and experiments in natural science by Roger Bacon who died in 1294, the great father of natural pbilosophy, as Mr. Brewer calls him, were probably made under the influence of this motive- he tod a minorite, though soon so far outstripping his

1 Monumenta Franciscana, vol. i. pret. p. mxx (Rolls Series). 
contemporaries in mental freedom and power that even his own order persecuted him.

But there was a large field of work within safe limits, and the popular preacher, who had to come and go, labouring among the craftsmen and the villans in this town or in that, could not. always spare time, rarely had the books or means, to search out original matter for himself. He must more often than not have relied not only upon recollections of the lecturers or readers he had heard expound the Bible, but upon books which were compiled, some by eminent friars themselves, for the express purpose of helping preachers. The illustrative matter found in these may come under three heads-exempla, or stories and anecdotes, fables, and the properties of things.

From ancient timés it had been usual to introduce stories, or exempla, into sermons by way of illustration of religious truth and precept, just as we find too in early ages the clergy encouraging the dramatic personation of characters in the Bible in order to fix the attention of the people. The stories were anecdotes drawn from personal knowledge; or example might be taken from any tradition or tale, historic, ecclesiastic, or legendary, because, as Pope Gregory sensibly pointed out, non nunquam mentes audientium plus exempla fidelium quam docentium verba convertunt. By a common process in word-history, from meaning the heart of a story exemplum grew to mean the story itself, and was thus commonly used by medieval preachers and writers. But the traces of these are lost or rare till the twelfth century, whether it were that the custom went out of use, or more probably that collections of popular sermons have not been preserved. There exist several collections of English homilies and sermons of this and previous periods, ${ }^{2}$ but their style is ecclesiagtical and that of the schools, very different from the more lively manner of the friars. Certain it is, however, that the friars saw the great value of story or fable for the almost colloquial persuasiveness of their preaching, although they were not the first to revive the practice. Guibert de Nogent at the beginning of the twelfth centary, in his book ' How a Sermon ought to be made,' compares the etory to the colours which adorn a picture; and Alain de Lille towards the end of the same oentory, in his treatise on the 'Art of Preaching,' enjoins the tale at the end of a sermon. The French prelate Jacques de Vitry was celebrated for the great number and variety of the stories or exempla which he introduced into his sermons for the people, probably preached between 1210 and $1228 ;^{\circ}$

- For example Old English homilies, published by the Elfric and Early Engliah Text Societies ; also some Old Kentish sermons in the issue 49 of the E.E.T.S.

- He was ordained priest in 1210, made bishop of Acre in 1217, and bishop of Tusoulum and cardinal in 1228. Professor P. Meyer thinks these were preached before 1217, while Lecoy de la Marche (La Chaire Francaise, 1868, p. 276) indicateg a possibly later date. 
the collection contained in his 'Bermones Valgares' is a perfect storehouse of tales, much used by succeeding preachers and compilers, which having long served to instruct and delight, and lead the way to better things, fell at last into oblivion, and has only recently been brought to the light of day. Etienne de Bourbon, a Dominican of Lyons, not long after (died 1261), in his 'Treatise of divers Matters for Preaching,' included again more exempla among the necessary equipment of the preacher, compiling a large collection for general use.

In England, too, contemporary with Jacques de Vitry, a Kentish man, Odo of Cheriton, near Folkestone, who had stadied in Paris, was preaching before the friars arrived, employing fables 'to point a moral.' His collection (in Latin), which was taken from a version of Phaedrus, was well known both in this country and abrosd. Evidence has recently been found indicating that there was also another collection of fables, in English, current in this country, which is now lost, but from which Marie de France translated her fables into French verse twenty or thirty years before Odo's time. So that there were exempla, or stories and anecdotes, and fables properly so called, the possible non-Christian origin of which did not at all trouble the preacher. Towards the latter part of the thirteenth century, some fifty or sixty years after the friars came hither, the general of the Dominicans, Etienne de Besançon, compiled an alphabetical collection of exempla, "Alphabetum Exemplorum,' a convincing proof of the extent to which the fashion already reached.

One of the ressons that induced Jacques de Vitry, bishop of Acre, to write his history of Jerussalem, as he tells $\mathrm{us}$ in the prologue, besides describing cities and places mentioned in the Scriptures which would be usefal for the better understanding of these, was to furnish material for preachers by giving particulars of the 'properties' of countries, diversas etiam terrae proprietates et

- Tha Exempla, or Illustratios Stories from the 'Sermones Vulgares ' of Jaoques de Vitry, edited by Profeseor T. F. Orane, of Cornell University, for the Folklore Bociety (London, 1890). This volume is the first attempt to put these onoe famous stories into print, although Th. Wright, without knowing Jacques de Vitry, printed some of them in his Latin Stories. It is a curions thing that the exempla of Jacques de Vitry were quite onknown in modern times till $\mathrm{K}$. Godeke in 1861, and Lecoy de la Marche in 1868 , brought them to the notice of scholars. Professor Crane gives the tert of 814 stories, with a short analysis in English of each, and notes containing raluable references to other varsions of the game tales. In an interesting and learned introdaction, besides some account of the bishop and his writings, he sketches the history of the exempla in sermons, devoting especial attention to the ase made of them after the time of Jacques, and giving such an account of the numerous colleetions and medieval literature connected with the subject in England and on the continent, anonymous or by acknowledged writers, down to the fifteenth centary, as is not to be found elsewhere. For the history of preaçbing even in England the volume will be indispensable.

' Hist. Orientalis, lib. i., in Bongars' Gesta Dei, 1611, tom. i. pt. 2. 
varias, ad maiorem praedicandi copiam adjungendo. This book, according to M. Barronx, was written between 1219 and 1223.6. The books that were as valuable to our friars as any, which threw open to them selectiong from travellers and natural philosophers of the past, were the treatises on the 'Moralised Properties of Things.' One of these, in seven books, was composed between 1281 and 1291, under the title 'A sevenfold Treatise of the Moralities of the hesvenly bodies, of the elements, of animals, fish, trees or plants, herbs, and precious stones,' 7 which sufficiently shows the intent of the anonymous author. Mach more important, however, was the great work of that Engliah Bartholomew the Minorite often erroneously called Bartholomew Glanvill. ${ }^{8} \mathrm{He}$, quite early in the years of his order, must have recognised the needs of his brethren. Something else besides fable and fiction mast be had ; they mast go back to the old idea that nature provides continual moral teaching for man. Before 1260 he composed 'De Proprietatibus Rerum,' in nineteen books, a vast collection, methodised, of the facts of natural history and the aciences known at that day, the fruit of mach labour and reading of many authors, suoh as Aristotle, Platio, Pliny, Dioscorides, Galien, Bt. Brsil, Beda, Alfred, Isidorus, the 'Physiologus,' Avicenna, Ovid, Virgil, and others, a list of whom he gives to the number of a hundred and five. How Bartholomew, being a Franciscan, ever obteined so many books, and the permission to use them, while his contemporary and fellow friar Roger Bacon, in his single-hearted search after truth in neture, was long denied necessary books and materials, is hardly to be explained except on the supposition that the responsible position of Bartholomew gave him authority, and at the same time did not tempt him beyond the bounds of orthodoxy. It wes a great thing to open up and spread the older learning, and show what store was here for the teacher of religion and morals. On these lines men might go further. He hopes ' that the symple, that may not for endlesse many bokys seke and fynde all the proprytees of thynges of the whiche holy wrytte makyth mencyon \& mynde, may here fynde somwhat that he desyreth,' ' to enable him to understand the enigmas of Scripture, handed down by the Holy Spirit under the symbols and figures of things natural and artilicial. He protests that it is all taken from others-saints, doctors, philosophers-nothing is of his own. "Albeit the things I have extracted are simple and unpolished, yet I have judged them of value to me, a plain man, and to my fellows.' The nineteen books range over all physical knowledge. Beginning with God and the angels, they include man, his soul, composition, body, ages, and diseases ; the world, frmament

- See Proteseor Crane'в Exempla, Introd. p. Ixrvi.

- Beo M. L. Delisle in Histoire Litteraire, w1. 384-836.

- Bee Dict of Nat. Biogr. rri. 409.

- Trevisa's translation, last ahapter. 
and elements; air, heat, and waters ; chronology and geography; birds, bessts, and fishes; stones and metals, herbs and plants; colours, measures, and music. His work (written in Latin) attained wide recognition, was bought by the Paris stadents, copied at Oxford, and translated into several languages, and, keeping its reputation for severel centuries, was printed from John of Trevisa's English translation, made in 1398, by Wynkyn de Worde in 1495. Finally this was taken as the foundation of a new edition by Stephen Batman in 1582.

Here, then, was help for the wandering preacher. And there is no doubt it was used with much effect during long years of unrecorded effort. What sort of man the popular preacher was, and how he used the means at his command in the early years of the fourteenth century, we are now for the first time able to learn through the good offices of our neighbours across the Channel, who, mindful of their ancient share in our language and literature, have recently placed another name, hitherto unknown, on the roll of English writers of that period..$^{10}$ As the review Romania and the publications of the French Society of Old Texts are not read in this country as much as might be wished, some account of the writings of Nicholas Bozon, Friar Minor, may not be unwelcome.

It is tantalising that nothing is known of Bozon beyond what the two chief manuseripts which contain his writings disclose. No trace of his family has as yet been found. He wrote in the corrupt French which was spoken and written in England about the close of the thirteenth and beginning of the fourteenth century, and of two or three personal incidents related by him one, touching a bishop of Lincoln who died in 1820, helps to indicate the time when he penned his 'Conteg' as within some twenty years after that date. We may also conjecture that he knew the north of England well, from his mention of the rivers Trent and Derwent, and of Scotch sheep which he had seen. This good friar also cultivated the art of poetry, fifteen pieces-and there may be others-being attributed to him with certainty, of which the greater part are found in one of the manuscripts (Cheltenham) containing the 'Contes.'

M. Paul Meyer, who has restored Bozon to the light of day, comparing the poems in this manuscript with others of which he had taken note, identifies several, some already in print, the author ship of which was previously unknown or wrongly attributed. Among these may particularly be mentioned one on the 'Goodness of Women,' in which Bozon tries to make amends for his rough treatment of the sex in other pieces. A curious allegorical poem, ' $\mathrm{L}_{\theta}$ Char d'Orgueil,' satirising fashionable follies and vices $\rightarrow$ a sort of

1) Los Contes moralists de Nicole Bason, frito minour, reoently esued by the Boaiété des Anoiens Textes Prançsis. (Paris: F. Didot.) 
' Sinner's Manual '-is perhaps the longest, ranning to five handred lines, and seems to have been the most widely known. All the poems are-unless we except the lines in which woman is compared to a magpie-on moral or religious subjects, such as the 'Passion,' treated in an interesting allegory, which is modelled on the lines of the medieval romance of chivalry; a prayer to the Virgin; a 'tretis' against 'denaturesce,' by which are meant unnatural quarrels among kindred, and so on. Finally, we have seven short sermons in verse on various moral subjects, the lest of which winds up thus :-

\section{Pryez Deu par Bosoun}

Ke vous fet ceo sermoun. Amen.

The full text of Bozon's collected poems has yet to be printed ; it were, perhaps, premature to expect this to be done while there is the hope of what further search may reveal. Meanwhile that on the 'Passion ' will be found printed at the end of Langtoft's ' Chronicle,' edited by the late Thomas Wright for the Rolls Series. 'De la Bonté des Femmes' and ' $\mathrm{La}$ Vie de Ste. Agnès ' are given in the introduction to 'Les Contes Moralisés,' which comprises a chapter on the author's poetry; and further description and extracts may be sought in the pages of Romania."

We have somewhat wandered from the 'Contes,' because the poems give essential aid in figuring to ourselves the man whose traits the former revesl. The object of his metaphorae, as the old rubric calls them, he states at the beginning. 'In this little book may be found many fine examples from various subjects, whereby one may learn how to avoid sin, to embrace goodness, and above all to praise the Lord who shows us how to live well by the nature of unreasoning crestures.' Our friar lays down what may becalled a series of sketches of sermons, the notions of which might be expanded, as no doubt he practically experienced, into discourses according to the need of the moment. ${ }^{12}$ Taking a sentence of Scripture $\rightarrow$ - ometimes more than one-he begins, not with that as text, but with some passage of fact drawn from Bartholomew or other writer ; he then shows how this is parallel to the Scripture teaching he wishes to convey, and winds up with a fable or an 'example' to catch bis hearers' fancy, in which he as often as not again brings in a Scripture text or two. The following specimen will show his manner.

The good clerk Basil tells as that ' God himself to labour and are not good to eat, as the horse and the ass; others are given for food and are of no use for labour, as sheep, pigs, fowls, and geese ;' others are only of use to guard and

"Romania, xiii. 497, artiole by M. P. Meyer.

13 The petif lioerat is indered in one of the manusoripts as ampla bona ef narraciona utiles pro sormonibus. 
clean the house, as dogs and cats. So it is in every household: some men are good for one occupation, others for another; and they ought not to reprove one another, for, says St. Paul, 'in one body are many members, and every one is worthy for his office.' And several further passages are cited from Corinthians and Erodus. Then follows this

Fabrila ad idem.-The peacock complained to Destiny that he was too unhappy, for he could not sing like the nightingale. Destiny responded, 'Thou hast so lovely a neck, a long teil which hanga on the ground; thy festhers are so tinted, some purple, others blue, some blood-red, others golden. Wherefore art thou grieved? Be contented with what thou hast.' And Paul says, ' Worthily walk in the vocstion to which you have been called' ( $(18)$.

Bozon deals with the moral aspects of all sorts of affairs in everyday life. His pious, exhortations are few; he not merely enforces religious duties, as payment of alms, shrift and contrition, resignation, \&c., but maxims of proverbial philosophy, such as that the poor and the rich cannot live together. He takes up his parable against certain ills, as 'against the proud,' 'against the passionate,' against the oppression of the poor by the great lords. He shows the dangers of this world, the evils of a flattering tongue. The strong bonds of human interest attract him; he wages war againgt sloth and licentionsness, and above all against covetousness. One finds no lofty thoughts, no rays of high spiritual vision in his pages, but honest homely truths, not seldom pointed with a shaft of ridicule or scorn which must have told home. Take the following, by which it appears that the Sunday question is older than is commonly supposed :-

There is a sea fish called koytar, which is heppy and joyous as long as it remains in salt water. But let it put its head up and the falling rain-water touch it, lo 1 it tarns on its stomach and pretends to be dying till it be restored by the natare of the salt water. So it is with many : the bitterness of this world, with labour and sorrow, pleases them all the week; but when they come to Sunday, and the Word of God begins to fall on them like dew, by their stomsoh they excuse themselves: the day is far gone and they must go to dinner.

He then relates the fable of the cock who finds a golden ring, jnstead of the pearl on a dunghill, and complains that it is not a grain of corn; 'thus many are more grieved by a short sermon than by aix week-days of labour and bodily affiction' ( $\$ 26)$.

The light which Bozon incidentally throws upon the social life of his time, and some of the opinions then current, is full of interest. Evidently a man of experiance among various orders of society, his sympathies are manifestly on the side of the poor as against their oppression and robbery by rich masters and lords, 
while many of his stories are pointed against the great and powerful. This characteristic in itself would be a commonplace, a feature belonging to most teachers and preachers. We find him, however, distributing his blame or admonitions to all classes; if on the one hand he declared that great men ought, like the gentle harrier, to be courteous to the lowly and peaceful (\$ $\$ 4)$, on the other he urged the performance of services due to the lord. It is plain that he did not consider that 'the bad serfa, who will not do what they ought to do,' were deserving of sympathy or encouragement : if their work was too heavy it was their own fault, not that of the lord (§130). No change of system was suggested; the cry for more liberty was not yet strong among this class, and did not find voice in Bozon. Great lords, according to him, often promise largely but give little; they prefer fools and flatterers to wise and true men as their companions. Many of them rely on their good birth, but their actions do not accord with it ; they are like bad mustard which passes under the name of fine mustard $(\$ \S 16,72,102)$. Poor men of low lineage are taking their place; these go to court and to school, and by hard work they attain courteousness (\$16). Yet he does not seem to approve of this ambition of the poor man to better himself, comparing those who seek to rise higher than their estate to a worm with wings, or to the rat who wished to marry the sun's daughter $(\$ 75)$. Herein he differs much from the reformers and preachers of the second half of his century, who, themselves taught by the people's discontent, strove to help them upward.

The machinery of law was familiar among the people, and our friar shows us what were some of the abuses. A purse of gold is like the magnet attracting iron; it draws the laws and decretals, lawyers and jurors following towards the false side (\$\$ 2, 32). Jurors, be says, both in lay and ecclesiastic courts, destroy truth and justice by their double-dealing and want of moral courage. 'A dozen are sworn in, and the greater part knows the truth; yet one alone, by fear, constraint, or favour, may draw them over to the false side, -so unstable are their hearts,' and he goes on to compare them to dogs of the chase led off on a false scent (\$52). If it is wished to try a plaint against a bailiff or a servant of the manorial lord, the trath cannot be got at owing to the collusion of his friende (\$ 55$)$. The bailiff or steward might hove friends; his duty is to look after the poor foll under him, and if he did this truly he would defend the poor fellows when the lord came graspingly among them. But many side with their lords and lay on still harder punishments than they do $(\$ 5)$.

A significant indication of the common want of independence and courage is given in one of the sections (121), which is illustrated by the fable of 'Who will bell the cat?' (here named 'Sire Badde.') 
Prelates are afraid to say the truth when great men threaten, and not only prelates but men in general; wrongs that are done in the country or in religious houses by superiors may be known and spoken of, and men promise to have them remedied, but when the right occasion arrives no one dare say a word. Comparing this with the two sections last mentioned, we get some evidence as to the position of the bailiff or steward in the feudal manor. Placed in the interest of the lord (lay or ecclesiastic) orer the labouring class, he became a sort of go-between; he ought to prevent the lord taking more then his just share of their lirelihood. On the other hand he had to reckon accounts with a master who was eager to get all the profit possible from his land; but the temptation was sometimes too great for his integrity. If he wished to cheat his master he favoured those under his control, who then took his part, and would not tell against him in the day of trouble with his lord, or when the usual periodical inquiries were made on the loet days. If he wished to ingratiate himself with his master, he was unduly strict and oppressive to the labourers.

\section{If the lord bids slay}

The steward bids flay,

according to the proverb quoted by the friar. In either case he took care to make friends of one or the other while looking after himself. Bozon thus corroborates the evidence of the statutes of Henry III and of Walter de Henley that these officers were frequently dishonest.

Out of the 145 titles or subject sections in the book no less than about eighty-five owe their suggestion to passages or notions drawn from Bartholomew's work, as has been found by careful comparison with certain of his chapters. The exempla and the fables so freely employed by Friar Nicholas are due to various sources, not always determinable even where the resemblance is olose, but many may be attributed to Jacques de Vitry, Odo de Cheriton, the bestiaries and other collections, including that used by Marie de France. One or two derive their origin from the legend of Barlaam and Josaphat. Some few, like the allegory of the Devil as a hunter with Seven Dogs, are here found in their earliest form: one is a story taken from Beda, another an incident from Matthew Paris; while there are several, such as the anecdote of the man with a doltish son, Hichebon, the story of the three rascals, Croket, Hoket, and Loket, and that of the miserly proctor of the Templars in the Court of Arches, which seem to be narrated out of Bozon's own hearsay. Several beautifal stories which had wide currency in the middle ages are naturally utilised; among these are the allegory of the pelican, the monk and the singing bird, and the child offering his breal to the statue of the infant Jesus. The accompaniment 
of the text by notes, rich in comparisons, will greatly assist those who like to pursue these old folk-tales further.

Bozon wrote at a time when French-French, that is, grown up on English soil since the Conquest, viz. during 250 years-hed long been in use as the literary language, and as a man of letters he too employed it. It would be an interesting inquiry whether he really preached in it. To the people of better class it would be the more familiar tongue, and probably also among the townsfolk of most degrees; but English was the language of the common poople. Our friar himself appealed to them by many an English proverb and phrase, a sure test; and in several of his stories he wakens up home feeling by giving his characters names in English. The seven dogs or vices bear English names. William Worldlyshame and Maude Machmisadventare are other instances. We have the testimony of the 'Cursor Mundi,' that long biblical poem forty or fifty years earlier than Bozon, that the common people spoke English, not French, when it was written, and it would almost seem by the protest-

Seldom was for ani chance

Englis tong preched in France--(Göttingen version)

that preaching in French was per contra usual in England. The lines may besr quoting once more :-

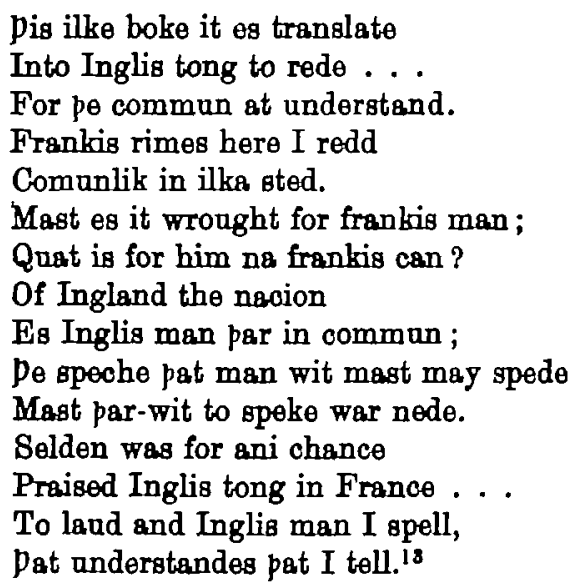

John of Lindberg, or whoever was the author of the 'Cursor,' addressed the pablic of the north, where we may suppose our friar was also known. A little later than Bozon came the chronicler Ralph Higden, who laments the place given to French among the country people. The truth seems to lie, as M. Meyer points out, in this, that Bozon ' addressed himself to the middle class, to the men who

13 Cotton version, 11. 232-250. The Gottingen and Cambridge versions have 'preched' for 'praised;' laud' should be 'lewd.' (Published by Early Engl. Text Sooiety.) 
knew English from birth, since the anthor often cites proverbs or phrases in that tongue, but who had learnt French more or less, and considered that language as more noble and ranking immediately after Latin.' The point is of much interest, both as regards the social life of the thirteenth and fourteenth centuries and the study of the forms taken by Anglo-French during its three hundred years' hold upon this realm.

On this latter sabject we must not dwell. How the English made a joke of mixing up the conjugations, and so formed the habit of using them wrongly; how the inflerions of other worde were confused, how Bozon preserved a better syntax than many-for these and much more we must refer to the interesting and lacid introduction which ushers our friar into modern society. To the philologist bis poetry is as welcome as his prose; for our present purpose it is something to know that ' there is not in all Anglo-Norman literature another work which can give us so complete a notion of what popular preaching was in Englend at the beginning of the fourteenth century.' Belonging by his tongue, his sympathies, and his labours to the body of the people of middle rank, he throws a welcome gleam of light on the modes of life and means of reform current under the second and third Edwards, and furnishes a not inconsiderable supplement to our knowledge of the lesser Franciscans in England.

Luox Toulans Bмтtн. 